\title{
Surface Roughness Optimization in Milling Aluminium Alloy by Using the Taguchi's Design of Experiment
}

Julia Hricova ${ }^{1}$, Natasa Naprstkova ${ }^{2}$

${ }^{1}$ Faculty of Environmental and Manufacturing Technology, Technical University in Zvolen, Studentska 26, 96053 Zvolen, Slovak Republic, E-mail: julia.hricova @tuzvo.sk

${ }^{2}$ Faculty of Production Technology and Management, J. E. Purkyne University in Usti nad Labem. Pasteurova 3334/7, 40001 Usti nad Labem. Czech Republic. E-mail: naprstkova@fvtm.ujep.cz

A unique combination of properties makes aluminium one of the most versatile engineering and construction materials. The aluminium alloys can be machined easily and economically if suitable practice and proper tools are used. A statistical design of experiments was performed to investigate the effect of selected cutting parameters and a cutting fluid on the surface roughness of AIMgSi1 aluminium alloy (EN AW 6082) machined by end milling. For the experimental procedure, three cemented carbide end milling cutters of diameter $12 \mathrm{~mm}$ with 3 cutting edges were used. The input parameters taken into consideration were helix angle, cutting speed, and using a cutting fluid. With application of ANOVA, the helix angle was investigated as the most significant parameter. The other ones were not statistically significant. To eliminate the negative impact of the cutting fluid on the health and environment, dry machining is recommended in this research.

Keywords: surface roughness, aluminium alloy, design of experiment, end milling

\section{Acknowledgment}

The authors wish to thank the Ministry of Education, Science, Research and Sport of the Slovak Republic for their financial support in the framework of research project KEGA 018TU Z-4/2014.

\section{References}

[1] LEGUTKO, S., KROLCZYK, G., KROLCZYK, J. (2014). Quality Evaluation of Surface Layer in Highly Accurate Manufacturing. In: Manufacturing technology, Vol. 14, No. 1, pp. 50-56.

[2] PISKA, M., METELKOVA, J. (2014). On the comparison of contact and non-contact evaluations of a machined surface. In: MM Science Journal, Vol. June, pp. 476-480.

[3] NOVAK, M. (2012) Surfaces with high precision of roughness after grinding. In: Manufacturing Technology, Vol. 12, No. 12, pp. 66-70.

[4] ISO 4287. (1997). Geometrical Product Specifications (GPS) - Surface texture: Profile method - Terms, definitions and surface texture parameters.

[5] GRZESIK, W. (2008). Advanced Machining Processes of Metallic Materials: Theory, Modelling and Applications, 472 p. Elsevier Science, Oxford, UK.

[6] BHANDARI, V. B. (2010). Design of Machine Elements, 934 p. Tata McGraw Hill Education, New Delhi.

[7] LYONS, A. R. (2007). Materials for Architects and Builders, $5^{\text {th }}$ Ed., 512 p. Routledge, New York.

[8] DAVIS, J. R. (1993). Aluminum and Aluminum Alloys, 784 p. ASM International, OH.

[9] SHAW, M., PIGOTT, J., RICHARDSON, L. (1951). The Effect of Cutting Fluid upon Chip-Tool Interface Temperature. In: Trans. of ASME. Vol. 73, pp. 45-56.

[10]CASSIN, C., BOOTHROYD, G. (1965). Lubrication Action of Cutting Fluids. In: J. Mech. Eng. Sci., Vol. 7, No. 1 , pp. 67-81.

[11]FUH, K. H., WU, C. F. (1995). A proposed statistical model for surface quality prediction in end-milling of Al alloy. In: International Journal of Machine Tools \& Manufacture, Vol. 35, No. 8, pp. 1187-1200.

[12]BENARDOS, P. G., VOSNIAKOS, G. C. (2002) Prediction of surface roughness in CNC face milling using neural networks and Taguchi's design of experiments. In: Robot Comput Integrated Manuf, Vol. 18, No. 5-6, pp. 343354.

[13] WANG, Y., CHANG, H. (2004). Experimental study of surface roughness in slot end milling Al 2014-T6. In: Int J Mach Tools Manuf, Vol. 44, No. 1, pp. 51-57. 
[14]OKTEM, H; ERZURUMLU, T; KURTARAN, H. (2005). Application of response surface methodology in the optimization of cutting conditions for surface roughness. In: J Mater Process Technol, Vol. 170, No. 1-2, pp. 1116.

[15]ZHANG, J.; CHENB, J.; KIRBY, D. (2007). Surface roughness optimization in an end milling operation using the Taguchi design method. In: J Mater Process Technol, Vol. 184, No. 1-3, pp. 233-239.

[16]BHARATHI, R. S; BASKAR, N. (2012). Application of particle swarm optimization technique for achieving desired milled surface roughness in minimum machining time. In: Expert Syst Appl, Vol. 39, No. 5, pp. 59825989.

[17]CIERNA, H., TAVODOVA, M. (2013). Using the design of experiment method to evaluate quality of cuts after cutting aluminum alloy by AWJ. In: Manufacturing technology, Vol. 13, No. 3, pp. 303-307.

[18] MAHESH, T. P.; RAJESH, R. (2014) Optimal Selection of Process Parameters in CNC End Milling of Al 7075T6 Aluminium Alloy Using a Taguchi-fuzzy Approach. In: Procedia Materials Science, Vol. 5, pp. 2493-2502.

[19]TAGUCHI, G., CHOWDHURY, S., WU, Y. (2005). Taguchi's Quality Engineering Handbook, 1662 p. John Wiley \& Sons, New Jersey.

[20]FENG, O., KAPUR K.C. (2008). Quality Engineering: Control, Design and Optimization, pp. 171-184. In: Handbook of Performability Engineering, Misra, K.B. (Ed.), Springer, London. 